\title{
Ecological Aspects and Regeneration of Sugar Palm in the Sasak Community Gardens of Kekait Village, West Nusa Tenggara, Indonesia
}

\author{
Anggit Haryoso ${ }^{1}$, Ervizal A. M. Zuhud ${ }^{2 *}$, Agus Hikmat', Arzyana Sunkar ${ }^{2}$, Dudung Darusman ${ }^{3}$ \\ ${ }^{1}$ Graduate School in Tropical Biodiversity Conservation Study Program, Faculty of Forestry, IPB University, \\ Academic Ring Road, Campus IPB Dramaga, Bogor, Indonesia 16680 \\ ${ }^{2}$ Department of Forest Resources Conservation and Ecotourism, Faculty of Forestry, IPB University, \\ Academic Ring Road, Campus IPB Dramaga, Bogor, Indonesia 16680 \\ ${ }^{3}$ Department of Forest Management, Faculty of Forestry, IPB University, Academic Ring Road, Campus IPB Dramaga, \\ Bogor, Indonesia 16680
}

Received December 5, 2019/Accepted February 14, 2020

\begin{abstract}
Sugar palm (Arenga pinnata Merr.) is one kind of palm that has multiple benefits on the Sasak community of Kekait Village. Despite its benefit, the information of sugar palm is barely unknown since the farmers depend on the nature cultivation. The Research aimed to analyze ecological aspects: composition, structure, the vegetation distribution, which includes the rate of regeneration and spatial distribution of sugar palm in the Sasak community garden in Kekait Village, West Lombok Regency, West Nusa Tenggara Province. The methods employed in the research is a single plot method with randomly selected. Obtained data are being analyzed quantitatively and qualitatively. The research successfully identified 68 species of 30 families plant. The majority of species are Meliaceae and Anacardiaceae families. The highest IVI from seedlings, saplings, poles, and trees are A. pinnata (52.09\%), T. cacao (22.72\%), G. gnemon (91.49\%), D. zibethinus (80.19\%). The vegetation structures showed a well-developed structure. The vegetation distribution in the farmers' garden indicated a clustered pattern within three strata; $B, C$, and $D$ strata. The regeneration level of A. pinnata categorized as fair sustainable with a clustered distribution pattern. The pattern is affected by the reproduction and distribution of A. pinnata seeds which carried out by Rinjani weasel (Paradoxurus hermaphroditus rinjanicus).
\end{abstract}

Keywords: diversity, Lombok, physiognomic, vegetation analysis, private garden

*Correspondence author,email:ervizal_amzu@yahoo.com

\section{Introduction}

Sugar palm (Arenga pinnata Merr.) is a plant with multiple benefits which could be found in several countries in the world, particularly in the tropical area. Burkill (1935) mentioned that the distribution of $A$. pinnata is in the Tropical Asia region, astronomically located between $\mathrm{N} 20^{\circ}-\mathrm{S} 11^{\circ}$. A. pinnata could be found almost in Indonesia with the different local names. Heyne (1987), Lutony (1993), Zuhud et al. (2014) mentioned that sugar palm has nearly 150 local names throughout Indonesia. The Sasak community in Lombok Island used to call sugar palm as nao or enao. Tenda et al. (2010) stated that the wide dispersion of $A$. pinnata in Indonesia confirmed the reason for sugar palm has high genetic diversity.

A. pinnata plant is one of the plants which is best known by the people of Indonesia. The Sibolangit people in North Sumatera and the Minahasa people in North Sulawesi have long utilized $A$. pinnata sap water as an ingredient for making traditional drinks known as tuak or saguer. On the other hand, the Kutai people in East Kalimantan processed palm sugar into sugar palm (Mogea et al., 1991). Sundanese people have known $A$. pinnata as kawung a long time ago for generations, especially in the Regencies of Banten, Bogor, Cianjur, and Garut (Febriyanti et al., 2017; Gunawan et al., 2017). In contrary to some of the areas mentioned, information about the utilization of $A$. pinnata in the Sasak Ethnic community in West Nusa Tenggara Province is still limited.

The Sasak community in Kekait Village, Gunungsari District, West Lombok Regency, West Nusa Tenggara Province, is one of the best palm sugar producers (Sukenti et al., 2016). However, the predicate has decreased in recent years. Nowadays, the farmers relied on wild palm sugar trees to fulfill their sugar palm productions. Farmers do not regenerate sugar palm intensively. Besides, the palm sugar distribution depends only on fruit-eating animals such as weasels (Paradoxurus hermaphroditus rinjanicus). In addition, community-owned gardens are increasingly 
reduced due to pressure of plantation land conversion. One of the particularly transformations is the construction of settlement facilities. Those factors make the presence of sugar palm under pressure. If the condition continues, it is feared that one day this plant might be extinct. This study aims to analyze ecological aspects: composition, structure, the vegetation distribution, which includes the rate of regeneration and spatial distribution of sugar palm in the Sasak community garden in Kekait Village.

\section{Methods}

Study area The study was conducted on the Sasak community in Kekait Village, Gunungsari Regency, West Lombok Regency, West Nusa Tenggara Province (Figure 1). The study started from October to the end of December 2018.

Procedures The characteristic of $A$. pinnata in the Sasak Community Garden, Kekait Village illustrated by vegetation analysis. The vegetation analysis conducted to determine structure, composition, regeneration level, and distribution pattern (Kusmana, 1997). In addition, Kusmana (1997) mentioned that vegetation analysis using single plot selection sized $100 \times 200 \mathrm{~m}$. The randomized selection at the Sasak community garden Kekait village lies at E116 6'36.4" $\mathrm{S}^{\circ} 30^{\prime} 16.7^{\prime \prime}$ coordinate point. The location selection is based on the primary survey and interview results with the local farmers who mentioned that almost the garden has a similar vegetation composition. Afterward, the plot divided into 50 subplots based on the level of seedlings, saplings, poles, and trees (Figure 2). The identification of the found species was held by making a collection of plant specimens (herbarium). Furthermore, related to the species identification, the process was involving local species identifier and staff of the Biodiversity Laboratory, Department of Biology, Faculty of Teacher Training and Education, University of Mataram.

Data analysis The data obtained from the plots being analyzed both quantitatively and qualitatively then presented descriptively. Soerienegara and Indrawan (1982) stated that quantitative analysis is done by calculating Important value index (IVI) from the sample plots using formulas as shown in Equation [1], Equation [2], Equation [3], and Equation [4].

Relative density $=\frac{\text { Density of a species }}{\text { Total density of all species }} \times 100 \%$
Relative frequency $=\frac{\text { Frequency of a species }}{\text { Total frequency of all species }} \times 100 \%$
Relative dominance $=\frac{\text { Frequency of a species }}{\text { Total frequency of all species }} \times 100 \%$

Importance value index (IVI) $=$ Relative density + Relative frequency + Relative dominance

Species dominance in the community is estimated from the high or low value of Simpson domination index as shown in Equation [5] and the Shannon-Wiener diversity index as shown in Equation [6] (Odum, 1971).

$D I=\sum(n \cdot i / N)^{2}$

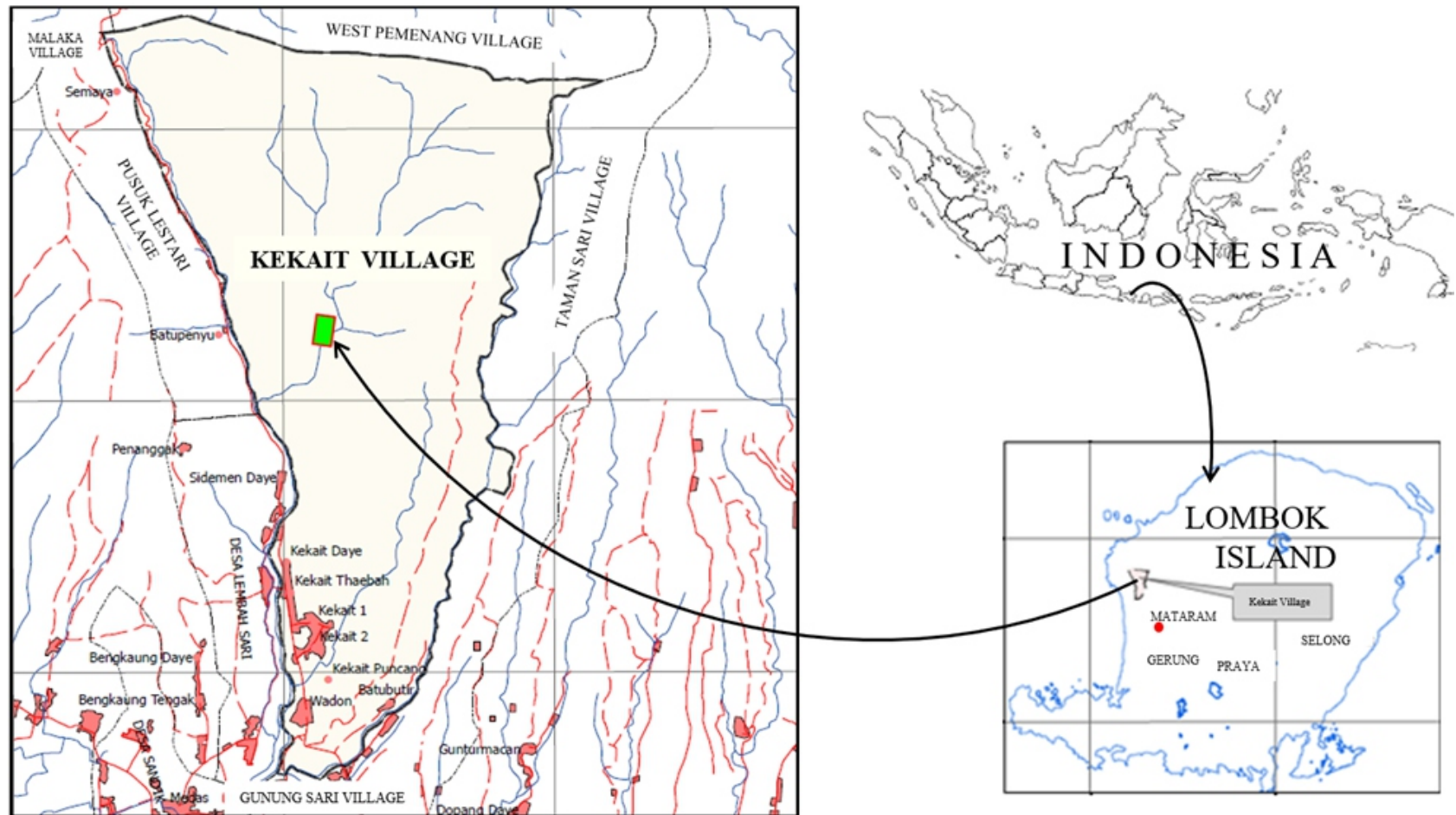

Figure 1 Research single plot in community garden at Kekait Village. 


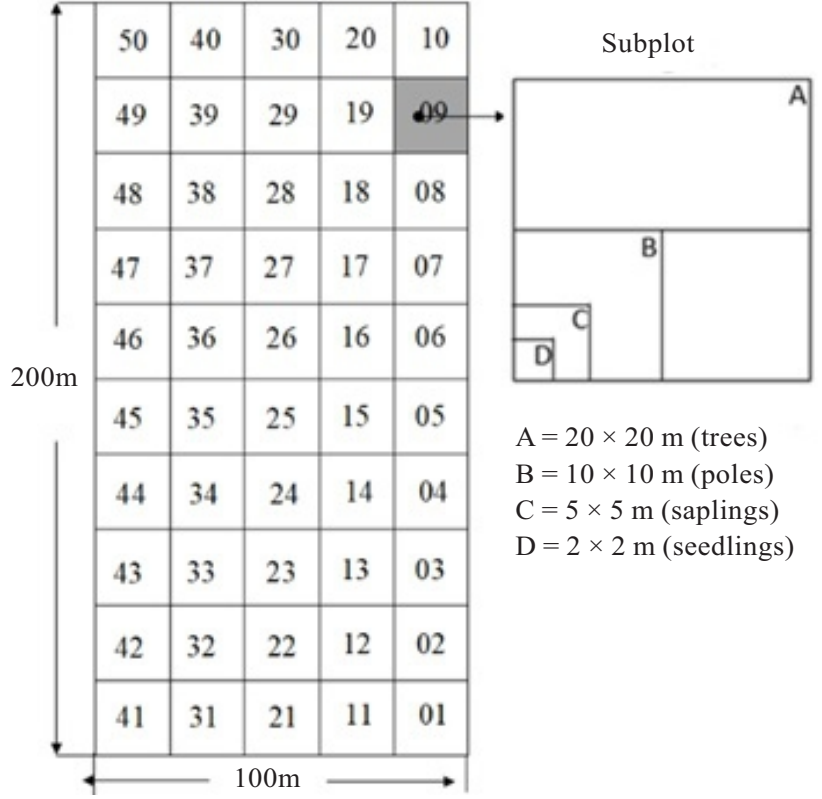

Figure 2 Single plot design.

The value of Simpson domination index categorized as: $0<$ $\mathrm{DI} \leq 0.5$ is lowest dominance; $0.5<\mathrm{ID} \leq 0.75$ is medium dominance; and $0.75<\mathrm{ID} \leq 1$ is highest dominance.

$H^{\prime}=-\sum \frac{n i}{N} \log \frac{n i}{N}$

The Shannon-Wiener diversity index $(\mathrm{H})$ categorized as $\mathrm{H}>3$ is high diversity; $1 \leq \mathrm{H} \leq 3$ is medium diversity; and $\mathrm{H}<1$ is low diversity (Odum, 1971).

The evenness species $E$ was determined by using the formula proposed by Pulov (Odum, 1971) as shown in Equation [7].

$E=\frac{\mathrm{H}^{\prime}}{\log \mathrm{S}}$

The Pulov evenness index categorized as: $0<\mathrm{E} \leq 0.5$ is depressed community; $0.5<\mathrm{E} \leq 0.75$ is unstable community; $0.75<\mathrm{E} \leq 1$ is stable community.

The distribution pattern of A. pinnata is calculated using a standardized Morisita index (Morisita, 1959).

$\operatorname{Id}=\mathrm{n}\left[\frac{\sum X_{i}^{2}-\sum X_{i}}{\left(\sum X_{i}\right)^{2}-\sum X_{i}}\right]$

Uniform index $(\mathrm{Mu})$

$\mathrm{Mu}=\frac{X^{2} 0.975-\mathrm{n}+\sum X_{i}}{\sum X_{i}-1}$

Clumped index $(\mathrm{Mc})$

$\mathrm{Mc}=\frac{X^{2} 0.025-\mathrm{n}+\sum X_{i}}{\sum X_{i}-1}$

Based on the calculation result of the uniform index and clumped index, the standard Morisita index (Ip) could be calculated with the following conditions:

If Id $\geq \mathrm{Mc}>1 \quad: \quad$ Ip $=0.5+0.5\left(\frac{I d M c}{n-M c}\right)$

$$
\begin{aligned}
& \text { If } \mathrm{Mc}>\mathrm{Id} \geq 0: \quad \text { Ip }=0.5\left(\frac{I d-1}{M u-1}\right) \\
& \text { If } 1>\mathrm{Id}>\mathrm{Mu}: \quad \mathrm{Ip}=-0.5\left(\frac{I d-1}{M u-1}\right) \\
& \text { If } 1 \geq \mathrm{Mu}>\mathrm{Id}: \quad \mathrm{Ip}=-0.5+0.5\left(\frac{I d-M u}{M u}\right)
\end{aligned}
$$

The Ip value categorized as follows: Ip $=0$ random distributed; Ip $>0$ clustered distributed; Ip $<0$ even distributed.

Qualitative analysis is conducted by using stratification analysis (Gopal \& Bhardwaj, 1979). Stratification analysis is used to explain the distribution of vegetation vertically. To be more specific, every species in the community has a different size. The species would not always stay in the same room vertically.

The regeneration condition assessment is based on criteria mentioned by: good, if the seedlings amount larger than saplings and the amount of saplings larger than the trees; fair, If the amount of seedlings larger than saplings and the amount of saplings less or similar with the trees; poor, if the amount of saplings lesser, more abundant, or similar with the trees (the species only available in the saplings, however unavailable at the seedlings level); none, if the species unavailable both in the saplings and seedlings level, but found in the level of the trees; new, if the species did not found in the level of the trees, nonetheless found at seedlings and saplings level. Whereas the assessment of plant sustainability is based on the category of plant population structure based on which are: sustain, if the condition of species regeneration included in the good category; fair sustain, if the condition of species regeneration included in the fair and poor category; less sustain if the condition of species regeneration included in the none or new category.

\section{Results and Discussion}

Composition The composition of plant ecosystems is a variation of flora species that composed the community. stated that the plant species ecosystem is a list of floristic plant species in the community. The available species on the location could be identified through species collection and identification. Based on the identification results on the community garden in the Kekait Village were found 12,311 plants individual grouped into 68 species and 30 families (Table 1).

Table 1 depicts the community garden of Kekait Village, which is a mixed garden resulted from traditional cultivation and developed by farmers. The mixed garden is an agricultural land planted with multi-years crops such as fruits, woods, etc. (Agriculture Minister Regulation Number 47/Permentan/OT. 140/10/2006, about guidelines of farming cultivation on the mountain land). A large number of plant species found in the garden indicated that the mixed garden in a fair condition. It was found 21 species of total plant species on each growth level (seedlings, saplings, poles, and trees). It could be the species have been appropriately regenerated.

Meanwhile, 47 plant species could only be found at one level or part of the growth level. Thus, the finding indicates there were competition among the individual either intraspecific or interspecific competition in all growth level. Intense competition or rivalry could affect some other 
Table 1 Plant species recapitulation and the appearance at each growth level

\begin{tabular}{|c|c|c|c|c|c|c|}
\hline \multicolumn{2}{|r|}{ Species name } & \multirow{2}{*}{ Family } & \multicolumn{4}{|c|}{ Growth level } \\
\hline Local & Scientific & & Sed & Sap & Pol & Tre \\
\hline Alpokat & Persea americana Mill. & Lauraceae & * & * & & \\
\hline Api-api & Ficus sp. & Moraceae & * & & & \\
\hline Aren & Arenga pinnata Merr. & Arecaceae & $*$ & * & $*$ & $*$ \\
\hline Bajur & Pterospermum javanicum Jungh. & Urticaceae & $*$ & $*$ & $*$ & $*$ \\
\hline Bay & Enterolobium cyclocarpum Griseb. & Fabaceae & $*$ & $*$ & $*$ & $*$ \\
\hline Badung & Garcinia parviflora Miq. & Clusiaceae & * & & * & \\
\hline Belimbing wuluh & Averrhoa bilimbi $\mathrm{L}$. & Oxalidaceae & & $*$ & & \\
\hline Biluk & Aegle marmelos Corr. & Rutaceae & $*$ & & & \\
\hline Bintangur & Calophyllum soulatri Burm. F. & Clusiaceae & $*$ & $*$ & & \\
\hline Boroq & Erythrina subumbrans Merr. & Fabaceae & $*$ & $*$ & $*$ & $*$ \\
\hline Buni & Antidesma bunius (L.) Spreng. & Euphorbiaceae & $*$ & $*$ & & \\
\hline Ceruring & Lansium parasiticum Osbeck. & Meliaceae & $*$ & $*$ & $*$ & $*$ \\
\hline Coklat & Theobroma cacao L. & Sterculiaceae & * & * & $*$ & * \\
\hline Dao & Dracontomelon dao Merr. & Anacardiaceae & * & * & $*$ & \\
\hline Durian & Durio zibethinus Rumph. & Malvaceae & * & * & $*$ & * \\
\hline Elak-elak & Alphonsea sp. & Annonaceae & * & & & \\
\hline Gamal & Grilicidia sepium Jacq. & Fabaceae & $*$ & $*$ & * & \\
\hline Gaok & Ficus fistula & Moraceae & * & & & \\
\hline Garu & Aglaia elliptica Blume. & Meliaceae & $*$ & $*$ & & \\
\hline Genggirang & Leea indica (Burm.F.) Merr. & Vitaceae & $*$ & & & \\
\hline Jambu air & Syzygium aqueum Burm.F. & Myrtaceae & * & & & \\
\hline Jambu jebed & Anacardium occidentale LL. & Anacardiaceae & $*$ & & & * \\
\hline Jambu rakte & Syzygium malaccense (L.) Merr. & Myrtaceae & $*$ & $*$ & $*$ & \\
\hline Jati & Tectona grandis $\mathrm{L}$. & Verbenaceae & & & $*$ & $*$ \\
\hline Jukut/salam & Syzygium claviflora Roxb. & Myrtaceae & $*$ & $*$ & * & * \\
\hline Katibango & Glochidion philippicum C.B.Rob & Euphorbiaceae & $*$ & & & \\
\hline Kecapi & Sandoricum koetjape Merr. & Meliaceae & $*$ & $*$ & $*$ & * \\
\hline Kelapa & Cocos nucifera $\mathrm{L}$ & Arecaceae & $*$ & & $*$ & $*$ \\
\hline Kemiri & Aleurites moluccana (L.) Willd. & Euphorbiaceae & & $*$ & & \\
\hline Kenari & Canarium asperum Benth. & Buseraceae & $*$ & $*$ & & \\
\hline Kepundung & Baccaurea racemosa Reinw. & Euphorbiaceae & $*$ & $*$ & $*$ & $*$ \\
\hline Ketapang & Saurauia bracteosa DC. & Actinidiaceae & $*$ & & $*$ & $*$ \\
\hline Klokos & Syzygium javanicum Miq. & Theaceae & $*$ & & & \\
\hline Klokos gunung & Eurya acuminata DC. & Theaceae & & $*$ & & \\
\hline Kopi & Coffea robusta Lindl. & Rubiaceae & $*$ & $*$ & $*$ & \\
\hline Kumbi & Tabernaemontana macrocarpum Jack. & Apocynaceae & $*$ & $*$ & $*$ & $*$ \\
\hline Lembokek & Ficus septica Burm.F. & Moraceae & $*$ & $*$ & & \\
\hline Lemudu & Actinodaphne procera Nees. & Lauraceae & $*$ & $*$ & $*$ & * \\
\hline Mahoni & Swietenia mahagoni (L.) Jacq. & Meliaceae & $*$ & $*$ & $*$ & $*$ \\
\hline Mangga hutan & Mangifera longifetiolatum King. & Anacardiaceae & $*$ & $*$ & $*$ & * \\
\hline Mangga wani & Mangifera caesia Jack exWall. & Anacardiaceae & $*$ & $*$ & $*$ & * \\
\hline Manggis & Garcinia mangostana L. & Clusiaceae & $*$ & * & $*$ & \\
\hline Melinjo & Gnetum gnemon L. & Gnetaceae & $*$ & $*$ & $*$ & * \\
\hline Mengkudu & Morinda citrifolia $\mathrm{L}$. & Rubiaceae & $*$ & * & $*$ & \\
\hline Mundah & Garcinia dulcis Roxb. & Clusiaceae & $*$ & & & \\
\hline Nangka & Artocarpus heterophyllus Lamk. & Moraceae & $*$ & $*$ & $*$ & $*$ \\
\hline Ombar-ombar & Chisocheton petandrus (Blanco) Merr. & Lauraceae & $*$ & * & & * \\
\hline Paok klikit & Mangifera laurina Blume. & Anacardiaceae & * & * & * & \\
\hline Pepaoan & Symplocos cochinchinensis (lour.) S. & Symplocaceae & $*$ & & & \\
\hline Peperik & Ficus ampelas & Moraceae & $*$ & & & \\
\hline Pinang & Areca cathecu L. & Arecaceae & $*$ & $*$ & * & \\
\hline Pucat & Placonia valida & Lecythidaceae & $*$ & & & \\
\hline Purut & Dysoxylum parasiticum (Osbeck) Kosterm. & Meliaceae & $*$ & $*$ & $*$ & $*$ \\
\hline Rajumas & Duob anga moluccana & Sonneratiaceae & & & $*$ & \\
\hline
\end{tabular}

Note: $\left.{ }^{*}\right)$ Found; Sed $=$ seedlings; Sap $=$ saplings $;$ Pol $=$ poles; Tre $=$ trees 
Table 1 Plant species recapitulation and the appearance at each growth level (continue)

\begin{tabular}{|c|c|c|c|c|c|c|}
\hline \multicolumn{2}{|r|}{ Species name } & \multirow{2}{*}{ Family } & \multicolumn{4}{|c|}{ Growth level } \\
\hline Local & Scientific & & Sed & Sap & Pol & Tre \\
\hline Rambutan & Nephelium lappaceum $\mathrm{L}$. & Sapindaceae & $*$ & $*$ & $*$ & $*$ \\
\hline Randu hutan & Gossampinus malabarica (DC) Merr. & Malvaceae & & & & $*$ \\
\hline Rengas & Gluta renghas $\mathrm{L}$. & Anacardiaceae & $*$ & $*$ & & \\
\hline Sandat & Canaga odorata Lam. & Annonaceae & $*$ & $*$ & $*$ & $*$ \\
\hline Saropan & Macaranga tanarius M.A. & Euphorbiaceae & $*$ & $*$ & & \\
\hline Sempage & Citrus aurantifolia (Christm.) Swingle. & Rutaceae & $*$ & $*$ & $*$ & $*$ \\
\hline Sengon & Albizia chinensis Merr. & Fabaceae & $*$ & & & \\
\hline Suren & Toona sureni (Blume.) Merr. & Meliaceae & $*$ & & & \\
\hline Tales & Leea aquleata B1. Ex Spreng. & Vitaceae & & $*$ & & \\
\hline Tapen & Mallotus dispar Blume. & Euphorbiaceae & & & & $*$ \\
\hline Telor ujat & Aglaia spinosa Merr. & Meliaceae & $*$ & & & \\
\hline Terep & Artocarpus clastica Reinw. & Moraceae & $*$ & $*$ & & \\
\hline Teruna semalam & Arthrophyllum javanicum Bl. & Araliaceae & $*$ & $*$ & $*$ & \\
\hline Waru & Hibiscus tiliaceus L. & Malvaceae & $*$ & & & \\
\hline
\end{tabular}

Note: *) Found; Sed = seedlings; Sap =saplings; Pol = poles; Tre = trees

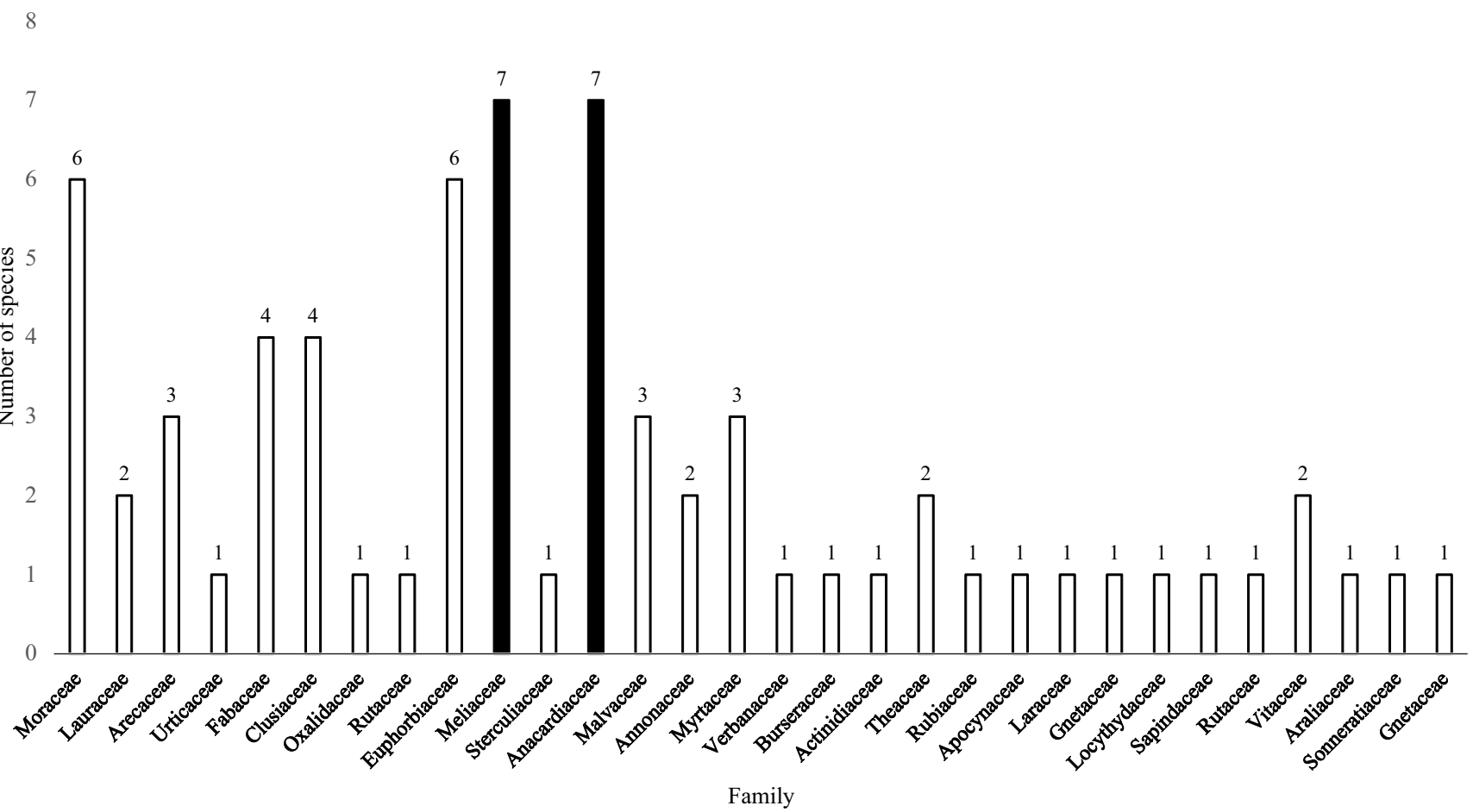

Figure 3 The number of species found in each family.

species only be found at specific levels such as Gossampinus malabarica and Mallotus dispar, which could only be found at tree level.

Meliaceae and Anacardiaceae families are the most dominated species in the community. Each of them has seven species discovered in the plot (Figure 3). The species that have been found from Meliaceae family as follows: Lansium parasiticum, Aglaia elliptica, Sandoricum koetjape,
Swietenia mahagoni, Dysoxylum parasiticum, Toona sureni, A. spinosa. Likewise, the species from Anacardiaceae that has successfully identified are Dracontamelon dao, Anacardium occidentale, Mangifera longifetiolatum, M. caesia, M. laurina, Symplocos cochinchinensis, Gluta renghas. The result interprets that the species from both families have higher tolerance and adaption from the surrounding environment in the research location. Odum 
(1971) mentioned that due to interaction processes among the plant species, there are species with a strong influence, or the strongest rival would be limiting other species to grow in the area.

Important value index Important Value Index (IVI) is a quantitative parameter that could be employed to determine the dominance level of species in the plant community. The higher the IVI of species means, the higher the dominance level of species and the contrary (Soegianto, 1994). A species could be crucial to the ecosystem if the IVI of seedlings and saplings level more than $10 \%$; the poles and trees level as many as $15 \%$ (Afrianti, 2007).

The vegetation analysis result (Table 2) shows that the highest dominance at seedlings level is $A$. pinnata (IVI = $52.09 \%$ ). According to Soerienegara and Indrawan (1982), species that have a dominant role in the community are characterized by the highest importance value index. The magnitude of IVI $A$. pinnata values at seedling growth level is mainly influenced by the number of the relative density value of $24.66 \%$ compared to other species. This means that $A$. pinnata seedlings have great adaptability. Saharjo and Gago (2011) referenced the domination of certain species in a community could occur if the species succeeded in locating the majority of available resources compared to other species.

The immense IVI value at saplings growth rate was $T$. cacao species, with a value of $22.27 \%$. The massive number IVI of $T$. cacao determined by the magnitude of individuals

Table 2 The highest IVI on each growth level

\begin{tabular}{|c|c|c|c|c|c|}
\hline Growth level & Species name & $\begin{array}{l}\text { Relative } \\
\text { density }\end{array}$ & $\begin{array}{l}\text { Relative } \\
\text { frequency }\end{array}$ & $\begin{array}{c}\text { Relative } \\
\text { dominance }\end{array}$ & $\begin{array}{l}\text { Importance } \\
\text { Value Index }\end{array}$ \\
\hline \multirow[t]{5}{*}{ Trees } & Durio zibethinus & 22.45 & 18.87 & 38.87 & 80.19 \\
\hline & Arenga pinnata & 21.41 & 13.21 & 40.78 & 75.40 \\
\hline & Gnetum gnemon & 16.19 & 14.62 & 10.00 & 40.81 \\
\hline & Cocos nucifera & 9.40 & 9.43 & 5.04 & 23.87 \\
\hline & Artocarpus heterophyllus & 6.01 & 8.02 & 2.58 & 16.61 \\
\hline \multirow[t]{5}{*}{ Poles } & Gnetum gnemon & 26.14 & 15.13 & 50.22 & 91.49 \\
\hline & Durio zibethinus & 13.90 & 14.76 & 14.94 & 43.60 \\
\hline & Theobroma cacao & 12.45 & 8.86 & 7.88 & 29.19 \\
\hline & Arenga pinnata & 8.71 & 6.64 & 3.71 & 19.06 \\
\hline & Morinda citrifolia & 0.21 & 0.37 & 16.04 & 16.62 \\
\hline \multirow[t]{7}{*}{ Saplings } & Theobroma cacao & 12.95 & 9.77 & - & 22.72 \\
\hline & Lansium parasiticum & 12.02 & 9.51 & - & 21.53 \\
\hline & Naphelium Lappaceum & 10.04 & 7.97 & - & 18.01 \\
\hline & Durio zibethinus & 8.52 & 8.48 & - & 17.00 \\
\hline & Gnetum gnemon & 8.63 & 7.46 & - & 16.09 \\
\hline & Swietenia mahagoni & 9.45 & 6.43 & - & 15.88 \\
\hline & Arenga pinnata & 7.12 & 5.40 & - & 12.52 \\
\hline \multirow[t]{5}{*}{ Seedlings } & Arenga pinnata & 46.57 & 5.52 & - & 52.09 \\
\hline & Lansium parasiticum & 4.37 & 5.52 & - & 9.89 \\
\hline & Tabernaemontana macrocarpum & 3.02 & 5.52 & - & 8.54 \\
\hline & Baccaurea racemosa & 5.39 & 3.05 & - & 8.44 \\
\hline & Dysoxylum parasiticum & 4.78 & 3.64 & - & 8.42 \\
\hline
\end{tabular}

Source: Primary data processed in 2018

Table 3 Diversity index $\left(H^{\prime}\right)$, dominance index $(D I)$, dan evennes index $(E)$

\begin{tabular}{lccc}
\hline Growth level & $\begin{array}{c}\text { Diversity index } \\
\left(H^{\prime}\right)\end{array}$ & $\begin{array}{c}\text { Dominance index } \\
(\mathrm{DI})\end{array}$ & $\begin{array}{c}\text { Evenness index } \\
(E)\end{array}$ \\
\hline Trees & 2.25 & 0.17 & 0.68 \\
Poles & 2.56 & 0.14 & 0.72 \\
Saplings & 3.04 & 0.07 & 0.80 \\
Seedlings & 3.14 & 0.09 & 0.77 \\
\hline
\end{tabular}

Source: Primary data processed in 2018 
of T. cacao and subplots where it found. Each could be seen from the high percentage of relative density $(12.95 \%)$ and relative frequency $(9.77 \%)$ as opposed to other species. The immense IVI means that $T$. cacao species have the highest role and dominance at the saplings level.

The analysis of IVI at the poles level depicted G. gnemon as the most dominant plant occupying $91.49 \%$. The massive number of $G$. gnemon's IVI determined by relative dominance and relative density, which are $50.22 \%$ and $26.14 \%$, respectively. The analysis shows that G. gnemon found at a very massive level and covered a wide area of the community garden. According to the farmers, it was planted in 1990 since there was a high demand for G. gnemon at that time. The high demand for $G$. gnemon has followed the increase of the price in the market; consequently, a massive G. gnemon plantation could be found at the garden plant. At a tree-level, the highest IVI level is found at D. zibethinus species (IVI $=80.19 \%$ ). The IVI level of $D$. zibethinus mostly determined by the relative density value and relative frequency, which are $22.45 \%$ and $18.87 \%$ sequentially. Therefore, D. zibethinus has been discovered frequently, and the number of an individual is higher compared to others. However, the coverage is lower compared to $A$. pinnata.

There are seven species at seedlings level that have an IVI significant value more than $10 \%$. The species are: T. cacao, L. parasiticum, N. lappaceum, D. zibethinus, G. gnemon, $S$. mahagoni, A. pinnata. While, at the poles and trees level there are five species have a IVI more than $15 \%$ which are; $G$. gnemon, D. zibethinus, T. cacao, A. pinnata, M. citrifolia (poles) followed by D. zibethinus, A. pinnata, G. gnemon, $C$. nucifera, A. heterophyllus (trees). Afrianti (2007) stated that a species categorized as vital if it has IVI value $>10 \%$ at seedlings and saplings level, and IVI value $>15 \%$ for poles and trees level.

Table 3 describes the mixed garden of community in the Kekait Village, which has medium to high complexity levels. The levels shown by the value of diversity index ranged from

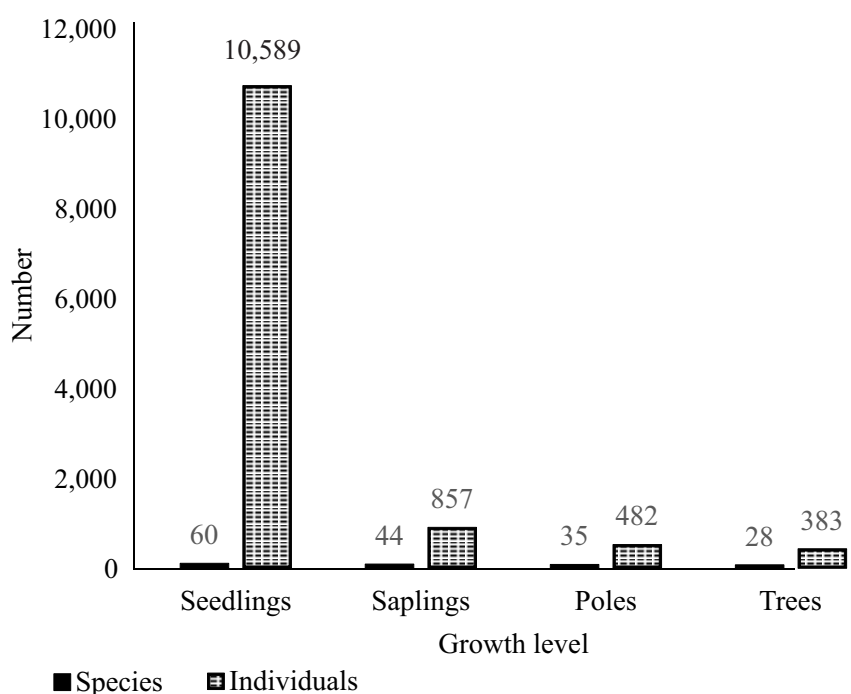

Figure 4 The amount of individual and species in each growth level.
$1 \leq \mathrm{H}^{\prime} \leq 3$ to $\mathrm{H}^{\prime}>3$. The high value of diversity index indicated that farmers had not prioritized particular species in their gardening system. Based on the dominance index calculation, the index value is ranged $0<$ ID $\leq 0.5$ at the whole growth level. The result means that there are none of the species dominated in the community's garden. Odum (1971) and Indriyanto (2006) explained that if the dominance index value is high, the dominance will concentrate on one particular species. However, if the dominance index value is low, the dominance would be concentrated into several species. Meanwhile, Arrijani (2008) discovered that if some particular species are dominated while others are not dominated, or the density value is lower, thus the evenness index would be lower.

The evenness index shows that saplings have a higher value, and this condition depicts the distribution of species on each subplot are even compared to another growth level. Furthermore, Arrijani (2008) emphasized the evenness index of species determined by other species on each subplot evenly. The more even the species in the research location means, the higher the evenness index. The community's stability tends to decline proportionally with the growth level starting from stable to unstable condition ranged $0.75<E \leq 1$ to $0.5<E \leq 0.75$. Odum (1971) stated that the more even of individual dispersion in the species, the higher the stability of the ecosystem.

Structure The vegetation structure consists of individuals composing stand community. The structure could be assessed vertically and horizontally. A horizontal structure describes the distribution of individual species in their habitat. While vertical structure shows the number of trees distribution based on the canopy. According to MuellerDombois and Ellenberg (1974) and Fachrul (2012), the vegetation structure consists of individuals composing stand community. Generally, the vegetation structure is embodied by three components which are: abundance or the number of individuals of each species arranged the vegetation; horizontal distribution of species arranged the vegetation, which describes the location and position of one member to another member; and stratification which is the distribution of plants in vertical space, displayed in a diagram profile depicting layers (stratum) starting from the seedlings, saplings, poles, to trees. Identification and inventory results can be seen in Figure 4.

Figure 4 describes the developed vegetation structure pattern, which drawn as a reversed "J curve". The pattern explains the vegetation structure in the community garden is similar to the primary forest structure, which is in good condition (Saputra et al., 2016; Ginting et al., 2017; Ariyanti $\&$ Mudiana, 2018). The condition presented by the amount of individual and species in the seedlings level is considerable compared to others and eventually decline proportionally with the growth level. Furthermore, this pattern could occur since the growing process of each species and individual different from each other. The process could be affected by several factors; one of them is competition among the species. The average regeneration level of species described by Muin and Astiani (2018) is along with the increase of trees 
age, the number of individuals decreased regarding competition among the vegetation in the habitat. Vickery and Daubenmire (1984) also mentioned that competition among the plants could occur between similar or different species due to those species settled in the same niche. Meanwhile, Soerianegara and Indrawan (1982) assumed the competition of similar or different species could have occurred because the have their life together while the resources (nutrient, minerals, water, growth, and light space) are limited.

According to Odum (1971), individuals in the population are experiencing one of three internal distribution patterns. The patterns are random, uniform, and clumped. In the case of a clumped pattern, the group could be in the same or a different size, and the group also randomly, uniformly, or clumpy distributed. In other words, the three internal distribution patterns could be generalized into five distribution patterns: (1) uniform; (2) random; (3) randomly clumped; (4) uniformly clumped; dan (5) clumped into groups.

Based on the above explanation, the vegetation in the Kekait community's garden is categorized as clumped into groups pattern (Figure 5). As mentioned by Indriyanto (2006), the clumped group distribution generally occurred in nature, either for plants or animals. Clumped distribution, according to Indriyanto (2006), could be developed because of several factors: (1) The diverse environment condition even though the area is narrow; (2) The reproduction pattern and the behavior of the individual which create a group of the colony; (3) Sexual attraction (mainly animals) could become the power to create a clumped distribution. The clumped distribution pattern in the community garden, Kekait village, indicated that there is less intervention from farmers managing their garden. The farmers only rely on nature, including in the process of regeneration. The community has never carried out intensive farm management, such as fertilizing and weeding. Farmers' activity is limited to thinning for certain species that grow in groups such as $A$. pinnata to reduce competition.
Soerienegara and Indrawan (1982) stated that in the tropical forest, the stratum could be grouped into five strata, sequentially from upper to bottom stratum: stratum A, stratum B, stratum C, stratum D, and stratum E. Each stratum explained as follow:

(1) Stratum A, the upper canopy formed of the trees higher than $30 \mathrm{~m}$. Generally, the trees have a more extensive canopy, and the canopy does not intersect with each other horizontally (discontinue).

(2) Stratum B, the canopy lies below stratum A, composed by trees between 20-30 m tall. The shape of the canopy at this stratum usually rounded or elongated. The space of trees tends to intersect horizontally closer (continue).

(3) Stratum C, the third layer from the upper part of the canopy made of trees with the height ranged from 4-20 $\mathrm{m}$. Trees of stratum $\mathrm{C}$ has fluctuated canopy. However, the canopy layer is thicker since the tree composition is dense.

(4) Stratum D is a canopy arranged from trees, brush, and shrubs. The height ranged from $1-4 \mathrm{~m}$. this layer is the $4^{\text {th }}$ canopy layer from the highest canopy.

(5) Stratum E, the lowest canopy composed by plant species, covered the land with the height $1 \mathrm{~m}$.

The stratification and result of stratification depicted (Figure 6) are based on the above criteria. There is three canopy stratification in a community garden, which are stratum B, C, dan D. this condition shows that trees with a height of more than 30 meters did not found in the research location. According to Soerienegara and Indrawan (1982), forest stratification in the tropical area has complete stratification ( 5 strata). Nonetheless, not all tropical forest has all of three strata mentioned. The condition depends on the growth and the compiled species in the community. Yusuf et al. (2005) described that the less encounter of Stratum A (height $>50 \mathrm{~m}$ ) could be affected by land clearing for cultivation and illegal logging in the community. There are ten species found in the stratum B. The space among the trees in this stratum tends to apart each other. This condition leads

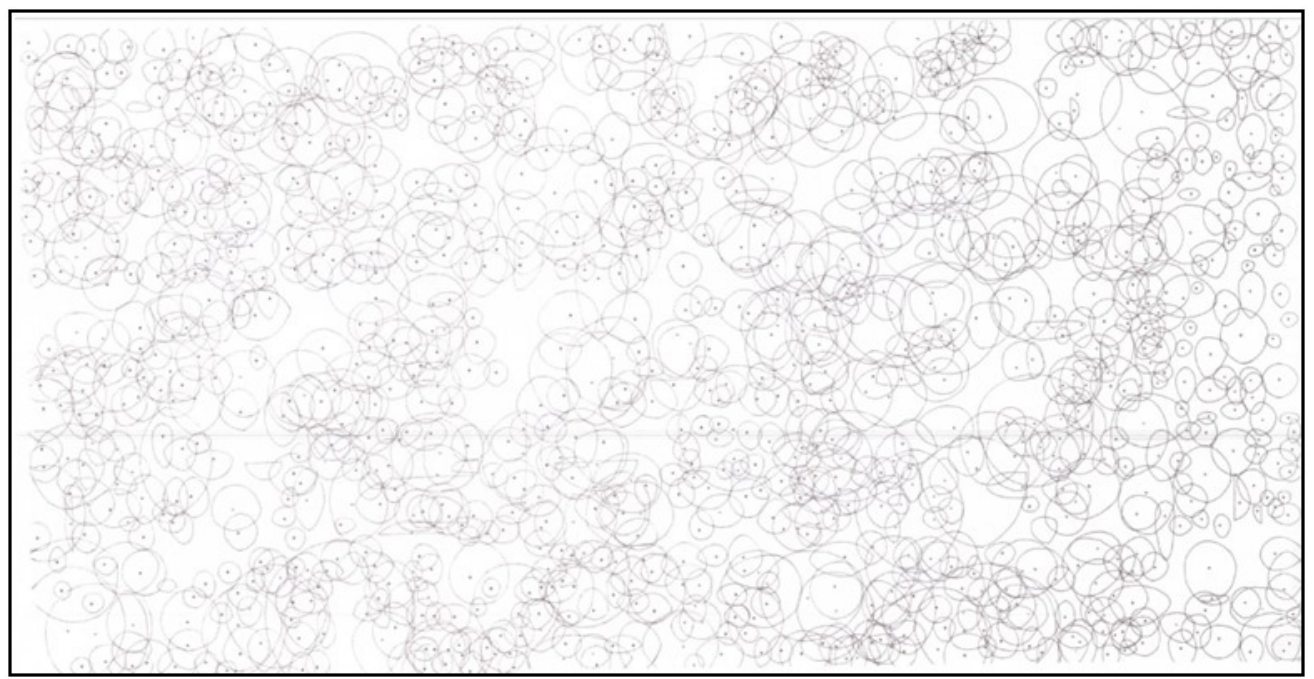

Figure 5 Horizontal stand structure in the community garden of Kekait Village. 
to discontinued canopy among each tree. In stratum $\mathrm{C}$, found 29 species trees. The $\mathrm{C}$ stratum dominated the community compares to the others. The domination occurred because there are many species numbers and tight composition of Stratum B so that the canopy position tends to continue despite there is some blank spot in the garden. There were found nine plants in the $\mathrm{D}$ stratum. The juvenile or poles plant was dominant in the D Stratum.

There were three species found in all stratums: $A$. pinnata, D. zibethinus, S. claviflora, and G. gnemon. The finding of these species indicated that they competed for each other at all canopy levels. Indriyanto (2006) explained that the stratification processes occurred because of two factors; firstly, competition among trees which resulted in the competent, excellent growth, and dominant trees in the community; secondly, the tolerance tree species of radiance intensity, thus the trees would growth fastly to achieved top position. The growth of this species would be hampered, which could lead to death if the growth space covered with other species.

A. pinnata regeneration level The enumeration of $A$. pinnata based on growth level shows that the number of saplings has the highest growth level. While the number of poles is smaller compared to trees. Besides, the number of saplings has the lowest individual number of the other growth level (Figure 6). Based on criteria proposed by Shankar (2001), the regeneration condition of $A$. pinnata in the community garden of Kekait Village categorized as sustainable fair.

Figure 7 shows the imperfect $\mathrm{J}$ reversed curve, and this pattern is different compared to the community garden in general (Figure 4). The structure pattern of $A$. pinnata in each growth level describes the disturbing growth level at saplings and poles level. The less number of $A$. pinnata at saplings and poles level compared to the number of individuals at trees level indicated intraspecific and interspecific competition. Moreover, this condition strengthened by the information from the farmers that since the beginning, there has never been extraordinary event triggered the disruption of $A$. pinnata vegetation such as natural disaster nor massive plant diseases, which could lead to reducing or disappearing of palm sugar at a specific time. Another aspect that influences the existence of palm sugar is the utilization of palm sugar by farmers. The farmers utilize palm sugar without cutting down the tree; they preferred to harvesting the sap water and its fruit (kolang kaling).

The intraspecific competition of $A$. pinnata has been started since the seed germinated. Mainly when the supply of food provided by endosperm exhausted. The $A$. pinnata must compete to obtain food supply form water and nutrient from the land. By contrast, the research found that there is less
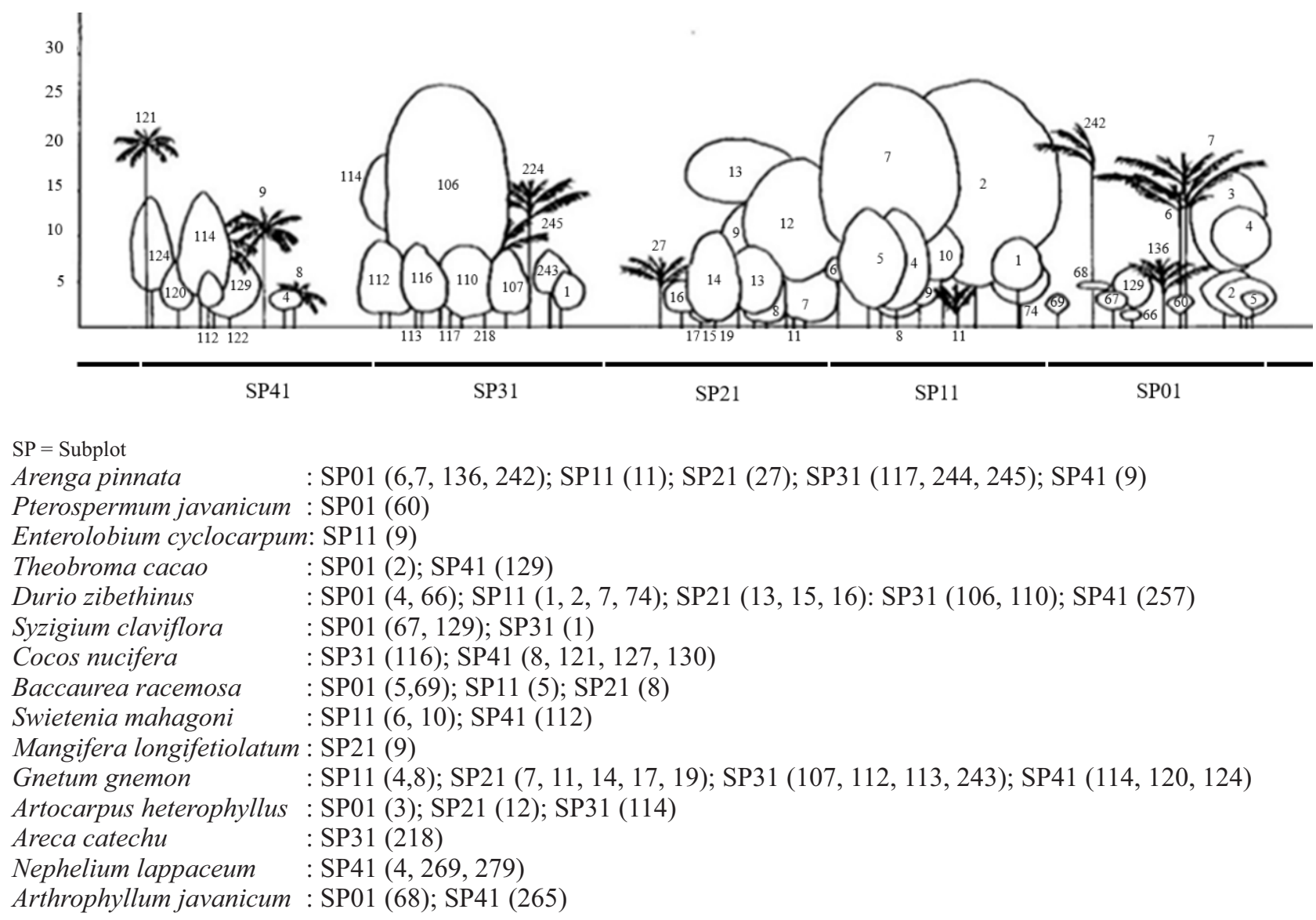

Figure 6 Vertical stand structure in the community garden of Kekait Village. 


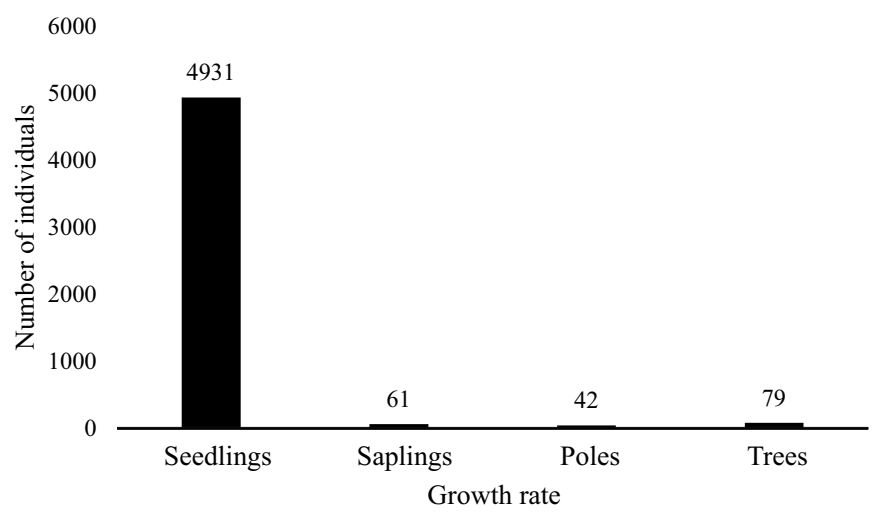

Figure 7 The regeneration level of $A$. pinnata.

intervention of farmers cultivating $A$. pinnata. The results of the omission lead to the death of a vast amount $A$. pinnata seedlings. Naturally, only the competition winner survived and continued to the next growth level. The intraspecific competition of $A$. pinnata continues at seedlings level, including competition for obtaining water, nutrient, and space to grow. The consequences are that individuals declined along with the increasing intraspecies competition continuously.

The interspecies competition started at the sapling and poles level, as shown in the visualization of vertical structure (Figure 6). The requirement needed to survive is increasingly complex, from nutrients, water, minerals, and growing space to compete for sufficient sunlight. Underpressed $A$. pinnata at saplings and poles level could be seen from the small value IVI of each growth level, which is $12.52 \%$ and $19.10 \%$ consecutively. The IVI value of $A$. pinnata at saplings level is in the $6^{\text {th }}$ order after $S$. mahagoni, G. Gnemon, D. zibethinus, $N$. Lappaceum, L. parasiticum dan T. cacao, while in the poles level the IVI level is in the $4^{\text {th }}$ order after T. cacao, $D$. zibethinus and G. Gnemon.

A. pinnata distribution pattern The $A$. pinnata distribution pattern shows a similar pattern in the community garden, which is clustered distributed (Odum 1971). The A. pinnata distribution pattern mostly influenced by its reproduction pattern. Susilowati et al. (2019) mentioned that the distribution pattern of species commonly clumped since the seed fallen near their broodstock. A. pinnata naturally would fall clumped around their broodstock in massive numbers. The $A$. pinnata seed would grow into the clumped plant along with the decline of its broodstock. The tendency of clustering patterns in groups of $A$. pinnata species is strengthened by the results of the Morisita distribution index at each growth level. At the seedling level, the value of Ip is 0.506 or Ip $>0$, meaning that the distribution pattern of $A$. pinnata species at the seedling level is clustered. At the saplings level, the value of Ip is 2,827 or Ip $>0$, meaning that the distribution pattern of $A$. pinnata species at the saplings level is clustered. Furthermore, at the poles level, the value of Ip is -0.086 or Ip $<0$ means that the distribution pattern of $A$. pinnata species at the poles level is evenly distributed. At the level of the trees, the value of Ip is 0.504 or Ip $>0$, meaning that the distribution pattern of $A$. pinnata species at the tree level is clustered.

The distribution pattern of $A$. pinnata species is also influenced by the mechanism of palm seeds spreading, which is assisted by an animal-spreading vector (zookori). Based on the observations and direct interviews in the field, it is known that $A$. pinnata seed dispersal animals are weasels, also known as Rinjani weasels (Paradoxurus hermaphroditus rinjanicus), and local people call them ujat. The characteristics of the palm fruit, which are fleshy, soft when ripe, yellow in color, and give off a distinctive aroma to be the main attraction for the ujat to eat it. Reece et al. (2011) implied that complex hormone interactions produced an edible fruit and enticed the animals to help spread the seeds. Fruit flesh becomes softer due to enzymes that digest the components of the cell wall. The color of the fruit usually changes from green to another color, such as: red, orange, or yellow. The fruit becomes sweeter when organic acids or starch molecules are converted to sugar.

Regarding the importance of weasels as a dispersal factor, their habitat and presence must be maintained properly. Reduction or loss of frugivorous habitat would affect the distribution pattern of $A$. pinnata seeds. This reduction ultimately would affect the disruption of the natural regeneration process. Willson and Traveset (2000) agreed that frugivores are essential seed dispersers and affect the spatial pattern of plant recruitment. The loss of fruit-eating dispersers could change the composition of tree communities and their natural regeneration.

\section{Conclusion}

The Sasak community garden in Kekait Village, West Lombok Regency, West Nusa Tenggara Province, is a mixed garden. They are composed of 68 species grouped into 30 families with the majority of species formed by Meliaceae and Anacardiaceae families. The highest IVI values from seedlings, saplings, poles to trees level are $A$. pinnata (52.09\%), T. cacao (22.72\%), G. gnemon (91.49\%), D. zibethinus $(80.19 \%)$. The structure of vegetation in the community garden shows developing structures pattern with reasonable regeneration rates. The distribution of vegetation in the community gardens is uniformly clumped with three canopy stratifications, namely strata B, C, and D. The regeneration rate of $A$. pinnata is included in the fair sustainable category with an inverted "J curve" at the saplings and poles level. The distribution pattern of $A$. pinnata species shows the same pattern as the distribution pattern of plants in community gardens, which is clustered. The distribution influenced by the reproduction and distribution pattern of $A$. pinnata seeds by the Rinjani ferrets (Paradoxurus hermaphroditus rinjanicus) vectors.

\section{Acknowledgment}

The authors would like to express their thanks to the Ministry of Environment and Forestry for the support of scholarships and research, the head of the Kekait Village who was giving permission and assistance in this research. Staffs of Biodiversity Laboratory, Department of Biology, Faculty of Teacher Training and Education of Mataram University, who assisted in the identification of plant species and field 
surveys, as well as the community and other parties who have helped carry out this research.

\section{References}

Afrianti, U. R. (2007). Ethnobotany study and conservation aspects of sengkubak (Pycnarrhena cauliflora (Miers.) Diels.) in Sintang District, West Kalimantan [thesis]. Bogor: IPB University.

Ariyanti, E. E., \& Mudiana, D. (2018). Vegetasi tumbuhan blok hutan waru-waru Cagar Alam Pulau Sempu. Media Konservasi, 23(3), 244-252. https://doi.org/10.29243/ medkon.23.3.244-252.

Arrijani. (2008). Vegetation structure and composition of the montane zone of Mount Gede Pangrango National Park. Biodiversitas, 9(2), 134-41. https://doi.org/10.13057. biodiv/d090212

Burkill, I. H. (1935). A dictionary of the economis product of the Malay Peninsula. London: Goverments of Straits Settlements.

Fachrul, M. F. (2012). Bioecological sampling method. Jakarta: Bumi Aksara.

Febriyanti, N., Agus, H., \& Zuhud, E. A. M. (2017). The ethnobotany and potential of sugar palm (Arenga pinnata Merr.) on the Kasepuhan Pasir Eurih community, Sindanglaya Village, Lebak Regency, Banten. Media Konservasi, 22(2), 171-80. https://doi.org/10.29244/ medkon.22.2.171-180

Ginting, Z. A., Manurung, T. R., \& Sisillia, L. (2017). The analisis of vegetation in village forest area in Nanga Yen Village, Hulu Gurung District, Kapus Hulu Regency. Jurnal Hutan Lestari, 5(3), 713-720. http://jurnal.untan.ac.id/index.php/jmfkh/article/viewFil e/21464/17390

Gopal, B., \& Bhardwaj, N. (1979). Elements of ecology. India: Department of Botany, Rajasthan University Jaipur.

Gunawan, R., Ramadhan, U.G., Iskandar, J., \& Partasasmita, R. (2017). Local knowledge of utilization and management of sugar palm (Arenga pinnata) among Cipanggulaan people of Karyamukti, Cianjur (West Java, Indonesia). Biodiversitas, 19(1), 93-105. https://doi.org/10.13057.biodiv/d190115

Heyne, K. (1987). Indonesia useful plants. Volume I-IV. Jakarta: Yayasan Sarana Wana Jaya.

Indriyanto. (2006). Forest ecology. Jakarta: Bumi Aksara.

Kusmana, C. (1997). Vegetation survey methods. Bogor: Bogor Agricultural University.

Lutony, T. L. (1993). Sweetener source plants. Jakarta: Penebar Swadaya.
Mogea, J., Seibert, B., \& Smits, W. (1991). Multipurpose palms: The sugar palm (Arenga pinnata (Wurmb) Merr.). Agroforestry Systems, 13(2), 111-29. https://doi.org/10. 1007/BF00140236

Morisita, M. (1959). Measuring of Interspecific Association and Similarity between Communities. Faculty of Science, Kyushu University, Series E (Biology), 3, (1) Fukuoka, Japan.

Mueller-Dombois, D., \& Ellenberg, H. (1974). Aims and methods of vegetation ecology. New York: New York Wiley.

Muin, A., \& Astiani, D. (2018). Population and vegetation structure of ramin (Gonystylus bancanus) in secondary forests of Ketapang District, West Kalimantan, Indonesia. Biodiversitas, 19(2), 478-84. https://doi.org/ 10.13057.biodiv/d190222

Odum, E. P. (1971). Fundamental of ecology ( $3^{\text {th }}$ ed.). Philadelphia: W.B. Sounders Company.

Reece, J. B., Urry, L. A., Cain, M. L., Wasserman, S. A., Minorsky, P. V., \& Jackson, R. B. (2011). Biology. New York: Pearson Education.

Saharjo, B. H., \& Gago, C. (2011). Natural succession after fires at secondary forest in Fatuquero Village, Railaco District, Ermera Regency-Timor Leste. Jurnal Silvikultur Tropika, 2(1), 40-45. Retrieved from http://journal.ipb.ac.id/index.php/jsilvik/article/downlo $\mathrm{ad} / 4145 / 2833$

Sanchez-Azofeifa, A., Powers, J. S., Fernandes, G. W., \& Quesada, M. (2013). Tropical dry forests in the Americas: ecology, conservation, and management. New York: CRC Press. https://doi.org/10.1201/b15417

Saputra, D., Ardiyansa, Indriyanto, \& Duryat. (2016). Composition, structure, and diversity of vegetation types in waterfall Wiyono Atas Wan Abdul Rachman grand forest park in Lampung Province. Sylva Lestari, 4(3), 83-95. https://doi.org/10.23960/js13483-96

Shankar, U. (2001). A case of high tree diversity in a Sal (Shorea robusta)-dominated lowland forest of Eastern Himalaya: floristic composition, regeneration and conservation. Current Science, 81(7), 776-86. Retrieved from https://www.researchgate.net/profile/ Uma_Shankar18/publication/237633655

Soegianto, A. (1994). Quantitative ecology; methods of population and community analysis. Jakarta: Penerbit Usaha Nasional.

Soerianegara, I., \& Indrawan, A. (1982). Indonesian forest ecology. Bogor: Department of Forest Management, Faculty of Forestry, Bogor Agricultural University.

Sukenti, K., Hakim, L., Indriyani, S., Purwanto, Y., \& 
Matthews, P. J. (2016). Ethnobotanical study on the local cuisine of the Sasak tribe in Lombok Island, Indonesia. Journal of Ethnic Foods, 3, 189-200. https://doi.org/10. 1016/j.jef.2016.08.002

Susilowati, Arida, Rachmat, H. H., Elfiati, D., \& Hasibuan, M. H. (2019). The composition and diversity of plant species in pasak bumi's (Eurycoma longifolia). Biodiversitas, 20(2), 413-18. https://doi.org/10. 13057.biodiv/d200215

Tenda, Elsje, T., Maskromo, I., \& Bambang, D. A. N. (2010). East Kalimantan Province exploration of sugar palm (Arenga pinnata Merr.) germplasm in East Kutai, East Kalimantan Province. Buletin Palma, 38, 88-94. https://doi.org/10.21082/bp.v11n38.2010.88-94
Vickery, M. L., \& Daubenmire, R. F. (1984). Ecology of tropical plants. New York: Wiley and Sons.

Willson, M. F., \& Traveset, A. (2000). The ecology of seed dispersal. In CAB International, Seeds: The Ecology of Regeneration in Plant Communities, 13, 85-110. Retrieved from https://pdfs.semanticscholar.org/8919/ 96f3400977845c67d8b38f2b8e167078facd.pdf

Yusuf, R., Purwaningsih, \& Gusman. (2005). Floristic composition and vegetation structure in Rimbo Panti Natural Forest, West Sumatra. Biodiversitas, 6(4), 266-271.https://doi.org/10.13057.biodiv/d060411

Zuhud, E. A. M., Sandra, E., Hikmat, A., Adhiyanto, E., \& Siswoyo. (2014). Reference book for medicinal plants in Indonesia. Volume VII. Jakarta: Dian Rakyat. 